Скорук, Ірина. «Польські прізвища на -owicz/-ewicz в антропоніміконі м. Луцька». Лінгвостилістичні студіï, вип. 13, 2020, с. 154-63.

Skoruk, Iryna. "Polish Surnames Ending in -owicz/-ewicz in the Anthroponymicon of Lutsk". Linguostylistic Studies, iss. 13, 2020, pp. 154-63.

УДК 811.162.1'373.232.1(477.82-2)

https://doi.org/10.29038/2413-0923-2020-13-154-163

\title{
ПОЛЬСЬКІ ПРІЗВИЩА НА -OWICZ/-EWICZ В АНТРОПОНІМІКОНІ М. ЛУЦЬКА
}

\author{
Ірина Скорук \\ Волинський національний університет імені Лесі Українки, \\ Луцьк, Україна
}

У статті проаналізовано польські прізвища лучан на -owicz/-ewicz, дібрані 3 метричних книг Державного архіву Волинської області й актових записів про народження Луцького міського рацсу. 3'ясовано, що аналізована модель репрезентує у своїй основі переважно особові імена й апелятиви 3 особовим та неособовим значенням. Аналіз фактичного матеріалу засвідчив велику продуктивність словотвірної моделі.

Ключові слова: антропонім, польська антропонімія, суфікс, відапелятивні прізвища, відіменні прізвища.

\section{POLISH SURNAMES ENDING IN -OWICZ/-EWICZ IN THE ANTHROPONYMICON OF LUTSK}

\author{
Iryna Skoruk \\ Lesya Ukrainka Volyn National University, Lutsk, Ukraine
}

The study of regional anthroponymy is one of the most relevant in modern linguistics. Surnames are considered mainly as a linguistic phenomenon in terms of linguistic and historical development, with a focus on their origin, surname appelative semantics, and specifics of name-formation patterns. The characteristic features of the economic, political, and cultural life of distant ancestors are elucidated via the case study of a surname origin. The author argues that specific features of the anthroponymic system may be associated with the linguistic interactions of those people who have been living in the same territory for a long time.

The article analyzes the Polish surnames in -owicz/-ewicz of people who lived in Lutsk. They were selected from the metric books of the State Archives of Volyn region and act records of the birth at Lutsk City Council. The ethnic varieties of the anthroponymic material allow identifying the Polish and Polonized surnames involved in the analysis. They are created on the basis of the East Slavic lexemes with the Polish elements. Therefore, the emphasis is laid on the identification of the Polish vocabulary and, in particular, its specific phonetic and word-forming elements.

It has been revealed that by its anthroponymy, the analyzed model represents mainly personal names (Deńkowicz, Jakubowicz) and appellations with personal (Niemiłowicz, Szczupłewicz) and non-personal meaning (Bażantowicz, Maskiewicz). The surnames of the

(C) Скорук I., Волинський національний університет імені Лесі Українки, 2020.

Це стаття відкритого доступу на умовах CC BY-NC 4.0 
people who live in Lutsk are the source pointing out the status of this or that family in the society officially identified since they explicitly reflect the time realities of the society in which they originated and functioned.

Key words: anthroponym, Polish anthroponymy, suffix, surnames motivated by appelatives, the last names of nominal derivation.

Вступ. Незважаючи на значну кількість праць про прізвища, що засвідчені в різних регіонах України, дослідження регіональної антропонімії одне з найактуальніших у мовознавстві. Дослідники розглядають особові спадкові назви як мовне явище в аспекті лінгвістичного та історичного розвитку, з'ясовують їх походження, допрізвищеву семантику й словотвір. Подекуди виявляють специфічні риси антропонімів, що можуть бути пов'язані з мовними взаємовпливами тих народів, які тривалий час проживають на одній території. Тому й заслуговує на увагу в цьому плані наукове осмислення особливостей ономастикону усіх народів, які здавна заселяли Україну.

Як засвідчують архівні матеріали, за кількістю населення в довоєнні роки в Луцьку переважали євреї й поляки. Наприклад, у 1925 році проживало 28210 осіб (євреїв - 16939, поляків - 6416, українців - 3084, росіян - 1102, німців - 340, караїмів - 51 та ін. Населення міста поступово зростало, причому в довоєнні роки переважно за рахунок польського населення.

Беручи до уваги специфічність території Волині, вважаємо, що однією 3 важливих проблем регіону взаємовпливів i перехрещення багатьох культур $\epsilon$ аналіз взаємодії антропонімних систем етнічних спільностей, зокрема української й польської. Вивчення українського антропонімікону у зіставленні його з польським (чи навпаки) виявляє не тільки спільні та відмінні аспекти цих двох антропонімних систем, а й визначає певну складність функціонування власних особових назв в антропонімній системі поліетнічної території.

Багатонаціональне місто Луцьк - одне з найстаріших в Україні (йому понад 900 років). За час існування воно входило до складу різних держав, проживало різні історичні епохи, які впливали на його соціальноекономічний i культурний розвиток та накладали відбиток на антропоніміконі, що формувався впродовж тривалого часу.

Матеріал і методи дослідження. Польські прізвища лучан на -owicz/ -ewicz дібрані з метричних книг Державного архіву Волинської області (1900-1944 рр. народження) й актових записів про народження Луцького міського рацсу (1945-1995 рр. народження). Фактичний антропонімний матеріал підтверджує мовні взаємовпливи українців і поляків та засвідчує специфіку антропонімікону м. Луцька.

У дослідженні використано прийоми інвентаризації й систематизації антропонімного матеріалу, щоб виявити його специфічні риси, характерні для польської антропонімї̈, та здійснити його структурно-семантичний 
аналіз. За допомогою описового, порівняльно-історичного та методу семантичного аналізу було здійснено лінгвістичну кваліфікацію засвідчених прізвищ, виявлено за їхніми твірними основами основні лексико-семантичні групи.

Джерела порівняльного аналізу: Abuzarova, Marta. Polskie nazwiska mieszkańców Drohobycza końca XVIII i początku XIX wieku na tle wschodniosłowiańskim. Poznań, 2014; Rymut, Kazimierz. Nazwiska Polaków: słownik historycznoetymologiczny. W 2 t. Kraków, 1999, 2001; Taszycki, Witold. Słownik staropolskich nazw osobowych. W 7 t. Wrocław, 1966-1987. Tomczak, Lucyna. Słownik odapelatywnych nazwisk Polaków. Wrocław, 2003; Українсько-польський, польсько-український словник, уклад. М. Юрковський, В. Назарук. Київ, 2003; Чучка, Павло. Прізвища закарпатських українців: історико-етимологічний словник. Львів, 2005. У зазначених словниках знаходимо генезу аналізованих прізвищ.

Мета дослідження - виявити польську мовну специфіку в засвідчених прізвищах на -ович/евич (-owicz/-ewicz) та визначити основні лексико-семантичні групи.

Результати дослідження та дискусія. Польським прізвищам притаманні кілька типових суфіксів, серед яких найпродуктивніші, на думку мовознавців, форманти -sk(i) та -owicz/-ewicz. Польські прізвищеві назви з цими суфіксами мають фіксації на території Польщі з XIII ст., а подекуди і з XII ст. (Abuzarova 55). Словотвірну модель на -sk(i) було описано в попередньому дослідженні (Скорук).

Прикметним є той факт, що суфікс -ович/евич (-owicz/-ewicz) не польського походження. Споконвічно польською була форма цього суфікса -owic/-ewic, а процес його творення (перетворення) відбувався під впливом української та білоруської мов.

Якщо прізвища на -ski/-cki кваліфікували в основному як шляхетські, то прізвища на -owic/-ewic, як зауважує Б. Унбегаун, розцінювали як соціально нижчі. В Україні та Білорусі, навпаки, відповідні прізвища на -ович/евич вважали дворянськими. «Коли після Люблінської унії 1569 р. привілеї польської шляхти поширилися також на українських та білоруських феодалів, суфікс -owicz/-ewicz, поряд із суфіксом -ski/-cki, став указувати на благородне походження і швидко витіснив польський суфікс -owic/-ewic» (Унбегаун 245-6). Останній соціально дискредитував себе ще й тим, що в багатьох польських діалектах вимовляли [ц] замість cz [ч], характерного для літературної мови, і порівняно з суфіксом -owicz/-ewicz суфікс -owic/ewic стали оцінювати як діалектний, «простонародний» i, отже, соціально нижчий. Поширення з XVI ст. суфікса -owicz/-ewicz призвело до того, що в 1574 році в польських шляхетських прізвищах суфікс -оwic був зафіксований востаннє (Abuzarova 57). Порівнюючи «статус» суфікса -ович/-евич (owicz/ewicz) в українських і польських прізвищах, П. Чучка зауважує, що «на території Польщі суфікс -ович у XVIII ст. був ознакою городянства і служив засобом свідомого ушляхетнення прізвищ (Чучка, Антропонімія 287). 
У нашому дослідженні польські прізвища на -owicz/-ewicz розглядаємо, як: 1) асимільовані українські прізвища: Artymowicz, Hawryśkiewicz, Uhrynowicz та ін.; 2) власне польські прізвища на зразок Brodowicz, Flisowicz, Klemensiewicz та ін., які у своїй структурі мають польську лексему й польський формант. А отже, з'ясувати походження прізвищ на -owicz/ewicz можна лише за їхньою твірною основою, однак у деяких випадках походження таких прізвищ визначити просто неможливо. До власне польських зараховуємо прізвища, які фонетично й морфологічно відповідають нормам польської мови, їхні твірні основи протягом кількох століть були сформовані на польському мовному грунті, якому передував праслов'янський, а також ті прізвища, «твірні основи яких утворені на базі запозичених лексичних одиниць, що вже згубили ознаки мови-джерела, пройшли тривалий процес адаптації до мови-реципієнта, тобто польської, i на сьогодні сприймаються як польські» (Abuzarova 87).

За твердженням мовознавців, формант -ович з часу свого виникнення служить активним засобом вираження родинної належності сина до батька. У давньоруській антропонімії цей суфікс утворював патроніми переважно від двоосновних повних імен, пізніше від прізвиськ та усіченосуфіксальних слов'янських і християнських імен. У давній антропонімії Волині, зазначає польська дослідниця І. Митнік, суфікси -ич, -ович, -евич належали до найбільш продуктивних протягом XVI-XVIII ст. безвідносно до соціальної належності особи (301).

Якщо прізвища на -ski/-cki переважно відтопонімні, то словотвірна модель на owicz/-ewicz репрезентує в антропонімній основі переважно антропоніми й апелятиви. Розглянемо деякі прізвища (асимільовані українські та власне польські), що похідні від особових імен. Зауважимо, що полонізація прізвища, сформованого на східнослов'янському мовному грунті, здебільшого відбувалася за допомогою зміни фонетичного складу прізвища або шляхом додавання польських формантів. Аналізуючи деякі прізвища з формантом -owicz/-ewicz, використовуємо означення польський тільки через окреслення вигляду суфікса (пор. польське -оwicz та укр. -ович/ -еwycz). Це такі прізвища, як Adamowicz, Bogdanowicz, Daniłowicz, Fedorowicz, Hawryśkiewicz (Гавриш, Гаврило), Hryniewicz (Гринь, Григоріŭ), Maksymowicz, Nazarowicz, Panasiewicz, Prokopowicz, Romanowicz, Supronowicz, Waselkiewicz, Wasilewicz (Василь/Wasyl (пол. Bazyli), Waśkiewicz та багато інших.

Daniełowicz <Danieł; Błaszkiewicz <Błażej, що 3 лат. blaesus 'шепелявий'; лат. Blaesius, гр. Blasios. У Польщі має фіксації з XII ст. (Abuzarova 157).

Прізвище Deńkowicz < Денько, що є народно-побутовим варіантом імені Денис / Denys. М. Абузарова зауважує, що пол. Dionizy зрідка вживалося на польських теренах, відоме здебільшого у формі Dziwisz, натомість українська форма, що в основі прізвища, має фіксації ще 3 Галицько-Волинської доби (158).

Ciechowicz - можливо, мотивоване скороченим Ciech- < Ciechosław. 
Filipowicz < Filip; Jakubowicz < Jakub; Janiewicz, Jankiewicz < Jan / Janek; Jurkiewicz < Юра / Jura (пор. пол. Jerzy, старопол. варіант Jura), гр. Georgios 'землероб'; лат. Georgius, ц.-сл. Георгий, пол. Jerzy (Jura, Jurg); укр. Юрій (скорочене Юра, пестливе Юрко) (Abuzarova 111). А отже, на сьогодні складно визначити, чи ім'я Юра/Jura (пестливе Юрко/Jurko) має українське коріння, чи збережена форма зі старопольського періоду.

Gryniewicz (як і Hryniewicz) < Гринь / Hryń < Григорій (пол. Grzegorz). Полонізація прізвища Gryniewicz виявляється і в додаванні суфікса -owicz, i в заміні в антропонімній основі українського [h] польським [g].

Kazimierzowicz < Kazimierz; Leszkiewicz < старопол. Leszek; Łukasiewicz, Łukaszewicz, Łukaszowicz < Łukasz / Лукаш; Klemensiewicz < Klemens (варіант Klement); Marcinkiewicz <Marcin/укр. Мартин; Marysiewicz <Marysia; Mosijewicz, Mossiewicz < Mosij; Maciejewicz < Macij (укр. Матвій); Niemirowicz < Niemir (давньослов'янське ім'я, поширене у східних слов'ян).

Pańkiewicz, Pankiewicz < укр. нар. Панько / Pańko < Пантелеймон (пол. Pantaleon) або Pankracy / Панкрат (з гр. Pankratis: pan 'все, весь' і kratis 'сильний'; лат. Pancratius. У Польщі має фіксації з XIII ст. у формах Pankrac, Pangrac, Pankrat (Abuzarova 162).

Romankiewicz < Роман / Roman, що з Середньовіччя відоме в Польщі, Е. Вольнич-Павловська та В. Шульовська зауважують, що ім'я Роман зазвичай з'являється поруч із прізвищами родин українського походження (Wolnicz-Pawłowska, i Szulowska 102).

Urbanowicz < Urban, лат. Urbanus 'міський, римський, житель міста'. У Польщі ім'я відоме з пізнього Середньовіччя, на сьогодні вживається зрідка, збереглося здебільшого в прізвищах (Abuzarova 164); Stachniewicz < Stach, що скорочене від Eфстахій / Eustachy; Szczepanowicz, Szcepanowicz $<$ Szczepan (укр. Степан, Стефан), Toтаszewicz < Tomasz.

Wawrzykiewicz < Wawrzyk <Wawrzyniec (3 лат. Laurentius, укр. Лаврентій); Więckowicz, Więnckowicz < Więcesław (варіанти Więcław, Wacław) - ім'я слов'янського походження, що означає 'більше славити', лат. Venceslaus (Abuzarova 167).

Антропонімний матеріал підтверджує, що твірними основами відіменних прізвищ $\epsilon$ імена різного походження й структури, та більшість із них поширена серед християн східного обряду, тобто серед православних і греко-католиків. Частина імен - це східнослов'янські форми, здебільшого українські, що також засвідчує значні впливи не тільки на розвиток окремого діалекту польської мови, а й на традицію вибору імен під час хрещення. «Мабуть, процес полонізації руських родів не відбувався в одному напрямку, польські родини, своєю чергою, також асимілювалися з українцями» (Abuzarova 170).

Похідні від топонімів такі прізвища: Niemenkiewicz - мотивоване назвою річки Niemen (пливе на території Литви, Білорусі, Росії); Kobrynowicz походить від назв населених пунктів Kobryń, що розташовані на території Білорусі та Волині, або назви річки Kobryń на Київщині. 
Перелічені географічні назви розташовані на українських землях, проте «похідні від них прізвища набули значного поширення на польських землях, через що й складно з'ясувати етнічну генезу (польську чи східнослов'янську)» (Abuzarova 112); Ossowicz - можливе утворення за назвою села Osowa (кілька сіл з такою назвою).

Серед відапелятивних розглянемо: 1) прізвища, мотивовані основами зі значенням особи (nomina personalia), та прізвища, мотивовані основами з неособовим значенням (nomina impersonalia). Апелятивам, що стали твірними основами прізвищ першої групи, вже було властиве особове значення. Апелятиви 3 неособовим значенням мали переносне метафоричне або метонімічне значення. І встановити те особове значення, завдяки якому неособовий апелятив став прізвищем, майже неможливо, оскільки процес такої номінації майже ніколи не обходився без гри фантазії (Чучка, Антропонімія 409). Дотримуючись підходу П. Чучки, відапелятивні прізвища цієї групи класифікуємо за прямим значенням їхніх твірних основ.

До групи прізвищ nomina personalia належать антропоніми, мотивовані апелятивами, які називали осіб за індивідуальними ознаками; за професією чи заняттям; за національністю; за місцем проживання; за їхніми родинними стосунками тощо.

На постійне заняття чи професію вказували твірні основи таких прізвищ: Bondarowicz < вednarz 'майстер, який виготовляв дерев'яні вироби'; Dudzikiewicz < dudziak / дудяк 'той, хто грає на волинці'; Flisowicz < flis 'особа, котра переправляла деревину річковим шляхом'; Gontowicz < gontarz / гонтар 'особа, що виробляє гонти або покриває ними дахи; gont/гонт 'дощечка для покриття даху'; Stelmachowicz < stelmach 'ремісник, котрий виготовляв дерев'яні частини для воза'; Wozniakiewicz < woźny / возний 'судовий урядовець у Польщі до XIX ст.'

Прізвище Войтович / Wojtowicz < Wojt < wojt / війm 'сільський староста'; у XIV ст. він означав 'голову місцевого самоврядування або міського суду'. Генетично давній полонізм wojt походить із німецької мови (нім. Voigt), він широко був уживаний на всіх землях Речі Посполитої (Чучка, Прізвища 121). Пор. також ст.-пол. Wojtowic (Taszycki 6: 184).

Прізвище Mazurkiewicz походить від етноніма mazur / мазур 'мешканець Мазовії'.

Прізвища, основи яких вказують на індивідуальні ознаки особи, зокрема:

а) на зовнішність: Chudzikiewicz < chudy / худий; Kołtunowicz < kołtun 'жмут збитого, брудного волосся на голові'; Kędzierowicz < kędzior 'локон'; наприклад, kędzierzawy 'кучерявий' (Українсько-польський 763); Niemiłowicz < niemiły 'негарний, неприємний'; Peliszkiewicz < pełechaty / пелехатий 'людина з довгим скуйовдженим волоссям'; Szczupłakiewicz < szczupłak < szczupły 'худорлявий, невеликий'; Szczupłewicz < szczupły; 
б) на особливості певних частин тіла: Brodowicz < broda / бородa; в антропоніміконі м. Луцька трапляються й інші прізвища з основою broda: Broda (ймовірно, той, хто мав бороду), Голіброда (жартома так могли називати майстра, що голив бороду); Гловякевич < Гловяк < głowa / головa 'той, хто має велику чи розумну голову'; Kolankiewicz < kolano / коліно; Paluszkiewicz < paluszek / пальчик, можливо так називали низькорослу людину; Wqqsowicz < wq̨s / вуса; з основою wq̨s засвідчені прізвища Венско, Wąnsiak; Волосєвіч / Wołosiewicz.

в) на фізичну ваду вказують прізвища: Garbowicz < garb / горб (i Garbicz), Безушкевич (Безушко) / Bezushkiewicz.

На особливості характеру, поведінки першоносія вказують такі власні спадкові назви: Бущерович < bucerz 'гордовита людина'; Dziugowicz < dziugać 'ковзатися, колисатися'; Gadułewicz < Gaduła < gaduła 'балакуха, базіка; балакун, щебетун' (Українсько-польський 114); Гайдусевич < Gaydus < gajdus 'груба, незграбна людина'; Kimakowicz < kimać 'дрімати'; Mysłowicz < myst- < туśleć / думати; Skrypuchiewicz < skrzypieć / скрипimu (3 українським $p$ замість $r z$ ); Hulkiewicz < gulać 'розважатися, веселитися'. М. Абузарова коментує: «апелятив hulać, як і слова hulaka, hultaj, hulanka та ін. прийнято виводити з українського апелятива гуляти (на що формально вказує початкове [h])» (110). I, покликаючись на мовознавців, називає XVII ст. початковою датою запозичення цих лексем з української мови в польську, здебільшого через літературні твори польських письменників 3 українських земель.

Про родинні стосунки інформують такі прізвища: Бабкевич / Babkiewicz < babka / баба, бабуся; Matkiewicz < matka / мaти; Swatkiewicz $<$ swat, swatek / cвam.

Розглянемо деякі прізвища, похідні від апелятивів з неособовим значенням. Такі прізвища класифікуємо за прямим значенням їхніх твірних основ. Наприклад, назвами тварин мотивовані такі прізвища: Baranowicz < baran, Byćkiewicz < byczek, byk / бик; Cielenkiewicz < cielę / теля; Dziciewicz < dzik 'дикий кабан' чи демінутива dziczek; Dzikowicz <dzik; Liśkiewicz < liszka / лис, лисиця; може, так називали хитру людину; Kozłowicz < kozioł / козел; Kunkiewicz < kuna / куниця 'хижий ссавець'; Łosiewicz, Łosiowicz < łoś / лocb; як прізвисько може мати значення 'кремезна людина'; Sobolkiewicz < soból / соболь; Turowicz < tur / тур 'вимерлі тварини роду бик'; Wołowicz < woł / віл.

Твірною основою прізвища Dubielewicz є назва риби dubiel / зубарик 'риба роду морських карасів';

Прізвища, основи яких утворені від назв птахів: Baźantowicz < bażant / фазан; Czaykewicz < czajka / чайка; Drozdowicz < drozd / дрізд; Gilewicz < gil / cнiгур.

До апелятивів твірних основ входять як назви різних видів тварин, так і загальні назви категорій (наприклад, Rybowicz, Puchowicz, Zwierewicz < zwierz). 
Назвами рослин мотивовані такі прізвища: Gruszkiewicz < grusza / груша; Lewandowicz < lawenda (з варіантами lawanda, lewanda) / лаванда; Łobodowicz < łoboda / лободa.

Виокремлюємо групу прізвищ, твірні основи яких утворені від назв продуктів харчування (Barszczykiewicz, Bułkiewicz, Sadłowicz < sadło / caлo; Serwatkiewicz < serwatka / сироватка 'плазма молока, що виходить під час його переробки на сир'); предметів побуту (Koszykewicz, Maskiewicz < maska / маска, maskować / маскувати; Pieckowicz < piec / niч; Mydłowicz < mydło / мило; Onuczkiewicz < старопол. описza / онуча 'шматок таканини, яким обмотують ноги перед взуванням'), знарядь праці (Dudkiewicz <dudka; Dudowicz <duda, на сьогодні $d u d a$ / волинка 'музичний інструмент'; Motykiewicz < motyka, Szydłowicz < szydło / шило 'груба голка'), одягу та прикрас (Czapkiewicz < czapka / шапка; Koralowicz < koral / намистина; Szubowicz < szuba) тощо.

В основах інших віапелятивних прізвищ вичленовуємо назви на позначення певних явищ природи (Burzanowicz < burza / буря; Mrózowicz < mróz / мороз); абстрактних понять (Koncewicz < koniec / кінещь), днів тижня (Sobotkiewicz < Sobota / cyбота) тощо.

Наприклад, прізвище Крижанович / Krzyżanowicz похідне від антропоніма < Krzyżan 3 апелятивною основою krzyż 'хрест'. будучи прізвиськом, антропонім Крижан (аналог відомий у м. Луцьку), міг утворити деривати, які позначали синів за найменуванням батька (Крижанівський, Крижанович).

Як і прізвища словотвірної моделі на -ski, антропоніми на -owicz / -ewicz (-ович/-евич), як було вже зазначено, не можна однозначно кваліфікувати як прізвища польські чи українські за походженням. Дослідниця польських прізвищ дрогобичан кінця XVIII - початку XIX ст. (Abuzarova 241) зауважує, що в основах антропонімів «закладено чимало апелятивів, що мають руський родовід, проте вже давно адаптувалися до норм польської мови і функціонують у ній тривалий час як свої: sotnik > Sotnicki, żubr > Zubrycki» тощо. До лексичної групи запозичень дослідниця зараховує й ті, що запозичені «не з руської мови, а з орієнтальних (здебільшого тюркських через часті турецько-татарські набіги) за посередництвом руської»: наприклад, kozak > Kozakiewicz .

Як полонізми або як результат антропонімної порубіжної взаємодії чи взаємовпливів, слід кваліфікувати деякі антропоніми на -евич, -ович, яких багато має досліджуваний антропонімікон (пор. вибірку на літеру Б): Бабкевич (Babkiewicz), Базантович (Bazantowicz), Базієвич (Bazijewicz), Байдович (Bajdowicz), Байкевич (Bajkiewicz), Бакулевич (Bakułewicz), Баранович (Baranowicz), Бартосевич (Bartosiewicz), Барщикевич (Barszczykiewicz), Беднарович (Bednarowicz), Безушкевич (Bezushkiewicz), (Бернадович (Bernadowicz), Бишевич (Byshewicz), Бондарович (Bondarowicz), Бояркевич (Bojarkiewicz), Брюхневич (Bruchniewicz), Будневич (Budniewicz), Будревич (Budrewicz), Бузікевич (Buzikiewicz), Буйневич (Bujniewicz), Булкевич 
(Bułkiewicz), Буранович (Burzanowicz), Буткевич (Butkiewicz), Бущерович (Bucerzowicz) та інші (наприклад, Гадзевич, Грудзевич, Вінцукевич, Дзюркевич, Дилович, Динович, єржикевич, Клинкевич, Лущакевич, Марушкевич, Озимкевич, Перетяткович, Петрулевич, Міляшкевич, Суткевич (sutek / сосок), Фалькевич, Шулькевич, Шушакевич, Шушкевич).

Отже, словотвірна модель на -ович/-евич (-owicz/-ewicz) - одна 3 найпродуктивніших у польській антропонімії, що й засвідчує досліджуваний антропонімний матеріал.

Висновки та перспективи досліджень. Засвідчені й проаналізовані прізвища жителів м. Луцька виявляють у своїй основі оніми (переважно власні особові імена різного походження та структури) й апелятиви, які безпосередньо відображають реалії тогочасного суспільства, в якому вони виникли та функціонують як головний засіб офіційної ідентифікації родини в суспільстві. Наше дослідження ще раз переконує, що тривале співжиття на одній території українців і поляків зумовлює взаємний вплив української й польської мов на національні антропонімні системи. I підтверджує, що власні особові назви зумовлені історично, що вони тісно пов'язані 3 культурою, традиціями, способом проживання народів. Перспективним вбачаємо подальше дослідження відіменних i відапелятивних польських прізвищ інших словотвірних моделей (наприклад, на -ik, -ek, -czak).

\section{Список використаної літератури}

Скорук, Ірина. Польські прізвища на $-s k i$ в антропоніміконі м. Луцька. Лінгвостилістичні студї, вип. 12, 2020, с. 183-93. doi:10.29038/2413-09232020-12-183-193.

Унбегаун, Борис. Русские фамилии. Перевод с англ. Москва: Прогресс, 1989.

Українсько-польський, польсько-український словник, уклад. М. Юрковський, В. Назарук, Київ: Школа, 2003.

Чучка, Павло. Антропонімія Закарпаття: монографія. Ужгород, 2008.

Чучка, Павло. Прізвища закарпатських українців: історико-етимологічний словник. Львів: Світ, 2005.

Abuzarova, Marta. Polskie nazwiska mieszkańców Drohobycza końca XVIII i początku XIX wieku na tle wschodniosłowiańskim. Poznań, 2014.

Mytnik, Irena. Antroponimia Wołynia w XVI-XVIII wieku. Warszawa: Uniwersytet Warszawski, 2010.

Rymut, Kazimierz. Nazwiska Polaków: słownik historyczno-etymologiczny. W 2 t. Kraków, 1999, 2001.

Taszycki, Witold. Słownik staropolskich nazw osobowych. W 7 t. Wrocław, 1966-1987.

Tomczak, Lucyna. Słownik odapelatywnych nazwisk Polaków. Wrocław, 2003.

Wolnicz-Pawłowska, Ewa, i Szulowska, Wanda. Antroponimia polska na kresach południowowschodnich XV-XIX wiek. Warszawa, 1998.

\section{References}

Skoruk, Iryna. "Polish Surnames Ending in -ski in the Anthroponymicon of Lutsk". Linguostylistic Studies, iss. 12, 2020, pp. 183-9, doi:10.29038/2413-0923-2020-12183-93. 
Unbegaun, Boris. Russkie familii. Translated from engl. Moskva: Progress, 1989.

Ukrainsko-polskyi, polsko-ukrainskyi slovnyk, edited by M. Yurkovskyi, V. Nazaruk. Kyiv: Shkola, 2003

Chuchka, Pavlo. Antroponimiia Zakarpattia. Uzhhorod: Papirus, 2008.

Chuchka, Pavlo. Prizvyshcha zakarpatskykh ukraintsiv: istoryko-etymolohichnyi slovnyk. Lviv: Svit, 2005.

Abuzarova, Marta. Polskie nazwiska mieszkańców Drohobycza końca XVIII i poczq̨tku XIX wieku na tle wschodniosłowiańskim. Poznań, 2014.

Mytnik, Irena. Antroponimia Wołynia w XVI-XVIII wieku. Warszawa: Uniwersytet Warszawski, 2010.

Rymut, Kazimierz. Nazwiska Polaków: słownik historyczno-etymologiczny. W 2 t. Kraków, 1999, 2001.

Taszycki, Witold. Słownik staropolskich nazw osobowych. W 7 t. Wrocław, 1966-1987.

Tomczak, Lucyna. Słownik odapelatywnych nazwisk Polaków. Wrocław, 2003.

Wolnicz-Pawłowska, Ewa, i Szulowska, Wanda. Antroponimia polska na kresach południowowschodnich XV-XIX wiek. Warszawa, 1998.

Стаття надійшла до редколегії 23.09.2020 